\title{
Origin of the Rheic Ocean: Rifting along a Neoproterozoic suture?
}

\author{
J. Brendan Murphy Department of Earth Sciences, St. Francis Xavier University, Antigonish, Nova Scotia B2G 2W5, Canada \\ Gabriel Gutierrez-Alonso Departamento de Geología, Universidad de Salamanca, 33708 Salamanca, Spain \\ R. Damian Nance Department of Geological Sciences, Ohio University, Athens, Ohio 45701, USA \\ Javier Fernandez-Suarez Departamento de Petrología y Geoquímica, Universidad Complutense, 28040 Madrid, Spain \\ J. Duncan Keppie Institute de Geologia, Universidad Nacional Autonoma de Mexico, 04510 Mexico D.F., Mexico \\ Cecilio Quesada IGME, Dirección de Geología y Geofísica, c/La Calera, 128760 Tres Cantos, Madrid, Spain \\ Rob A. Strachan School of Earth and Environmental Sciences, University of Portsmouth, Portsmouth PO1 3QL, UK \\ Jarda Dostal Department of Geology, St. Marys University, Halifax, Nova Scotia B3H 3C3, Canada
}

\section{ABSTRACT}

The Rheic Ocean is widely believed to have formed in the Late Cambrian-Early Ordovician as a result of the drift of periGondwanan terranes, such as Avalonia and Carolina, from the northern margin of Gondwana, and to have been consumed in the Devonian Carboniferous by continent-continent collision during the formation of Pangea. Other peri-Gondwanan terranes (e.g., Armorica, Ossa-Morena, northwest Iberia, Saxo-Thuringia, Moldanubia) remained along the Gondwanan margin at the time of Rheic Ocean formation. Differences in the Neoproterozoic histories of these peri-Gondwanan terranes suggest the location of the Rheic Ocean rift may have been inherited from Neoproterozoic lithospheric structures formed by the accretion and dispersal of periGondwanan terranes along the northern Gondwanan margin prior to Rheic Ocean opening.

Avalonia and Carolina have Sm-Nd isotopic characteristics indicative of recycling of a juvenile ca. 1 Ga source, and they were accreted to the northern Gondwanan margin prior to voluminous late Neoproterozoic arc magmatism. In contrast, $\mathrm{Sm}-\mathrm{Nd}$ isotopic characteristics of most other peri-Gondwanan terranes closely match those of Eburnian basement, suggesting they reflect recycling of ancient ( 2 Ga) West African crust. The basements of terranes initially rifted from Gondwana to form the Rheic Ocean were those that had previously accreted during Neoproterozoic orogenesis, suggesting the rift was located near the suture between the accreted terranes and cratonic northern Gondwana. Opening of the Rheic Ocean coincided with the onset of subduction beneath the Laurentian margin in its predecessor, the Iapetus Ocean, suggesting geodynamic linkages between the destruction of the Iapetus Ocean and the creation of the Rheic Ocean.

Keywords: Pangea, Rheic Ocean, Neoproterozoic suture, Sm-Nd data, terranes.

\section{INTRODUCTION}

The tectonic evolution of the Paleozoic Era is dominated by early Paleozoic continental dispersal and ocean development, followed, in the middle to late Paleozoic, by convergence culminating in collisional tectonics that led to the amalgamation of Pangea (Fig. 1). During this time, terranes were transferred from Laurentia to Gondwana (Thomas and Astini, 1996) and from Gondwana to Laurentia (van Staal et al., 1998; Keppie et al., 2003). Two key oceans, the Iapetus and Rheic, developed during the early Paleozoic by fundamentally different rifting mechanisms. It is generally accepted that the Iapetus Ocean developed in the Early Cambrian with the separation of two major continents (Laurentia and Gondwana, e.g., Cawood et al., 2001), but that the Rheic Ocean initiated in the Late Cambrian-Early Ordovician with the rifting of peri-Gondwanan terranes (e.g., Avalonia and Carolina) from the northern (Amazonia West African) margin of Gondwana (Fig. 1; van Staal et al., 1998; Cocks and Torsvik, 2002).

On separation, these terranes defined the boundary between of the expanding Rheic Ocean to the south and the contracting Iapetus Ocean to the north during the middle to late Paleozoic (Fig. 1; Cocks and Torsvik, 2002; Stampfli and Borel, 2002). The implications of such differences in rift mechanisms are profound, yet they have received little attention in the literature.

Iapetus was largely closed by either the mid-Silurian (e.g., Hibbard et al., 2002) or the Devonian (Hatcher, 1989) through LaurentiaBaltica collision and peri-Gondwanan terrane accretion. It was the closure of the Rheic Ocean, some 100 million years later, that led to the assembly of Pangea through the collision of Laurentia-Baltica with Gondwana. In this paper, we focus on the processes that determined the site of initial rifting and development of the Rheic Ocean. We show that the peri-Gondwanan terranes that separated from the northern Gondwanan margin to form the Rheic Ocean had previously been accreted to this margin in the Neoproterozoic, whereas those that remained on this margin had formed part of cratonic Gondwana. This implies that rifting was focused on Neoproterozoic sutures between the accreted terranes and cratonic Gondwana and, more generally, that (1) ocean development along continental margins shows a remarkable degree of structural inheritance, (2) accreted terranes are susceptible to subsequent rifting and may therefore experience repeated episodes of accretion, and (3) the contrasting thermal conditions of intracratonic and continental margin breakup produce quite different styles of rifting.

\section{EVOLUTION OF THE IAPETUS AND RHEIC OCEANS}

The Iapetus Ocean (Fig. 1A) opened in stages between ca. 600 Ma (Laurentia-Baltica) and $550 \mathrm{Ma}$ (Cawood et al., 2001). The subsequent onset of convergence is recognized by the development of arcrelated mafic complexes in the Late Cambrian-Early Ordovician (van Staal et al., 1998). Iapetus was closed to the north in the early to midSilurian by the collision between Laurentia and Baltica to form Laurussia and, to the south, by the accretion of Gondwana-derived terranes, such as Avalonia and Carolina, to Laurentia and Baltica, either by the Late Ordovician to mid-Silurian (Hibbard et al., 2002) or by the Devonian (Hatcher, 1989).

Although a small ocean existed between Avalonia/Carolina and the Amazonian-West African margin of Gondwana in the Cambrian (Keppie et al., 2003), the main Rheic Ocean opened in the Late Cambrian-Early Ordovician (Fig. 1A) (e.g., Cocks and Torsvik, 2002). By the end of the Paleozoic, the Rheic Ocean had been closed by the collision between Gondwana and Laurussia, which produced the Appalachian-Variscan orogen, one of the key events in the formation of Pangea (van Staal et al., 1998).

\section{NEOPROTEROZOIC EVOLUTION OF PERI-GONDWANAN TERRANES}

A wealth of paleontological, paleomagnetic, and isotopic data indicates that a number of terranes in the Appalachian and Variscan orogens were positioned along the northern margin of West Gondwana in the Neoproterozoic and early Paleozoic at considerable latitudinal distance from Laurentia (e.g., Cocks and Torsvik, 2002; Landing, 


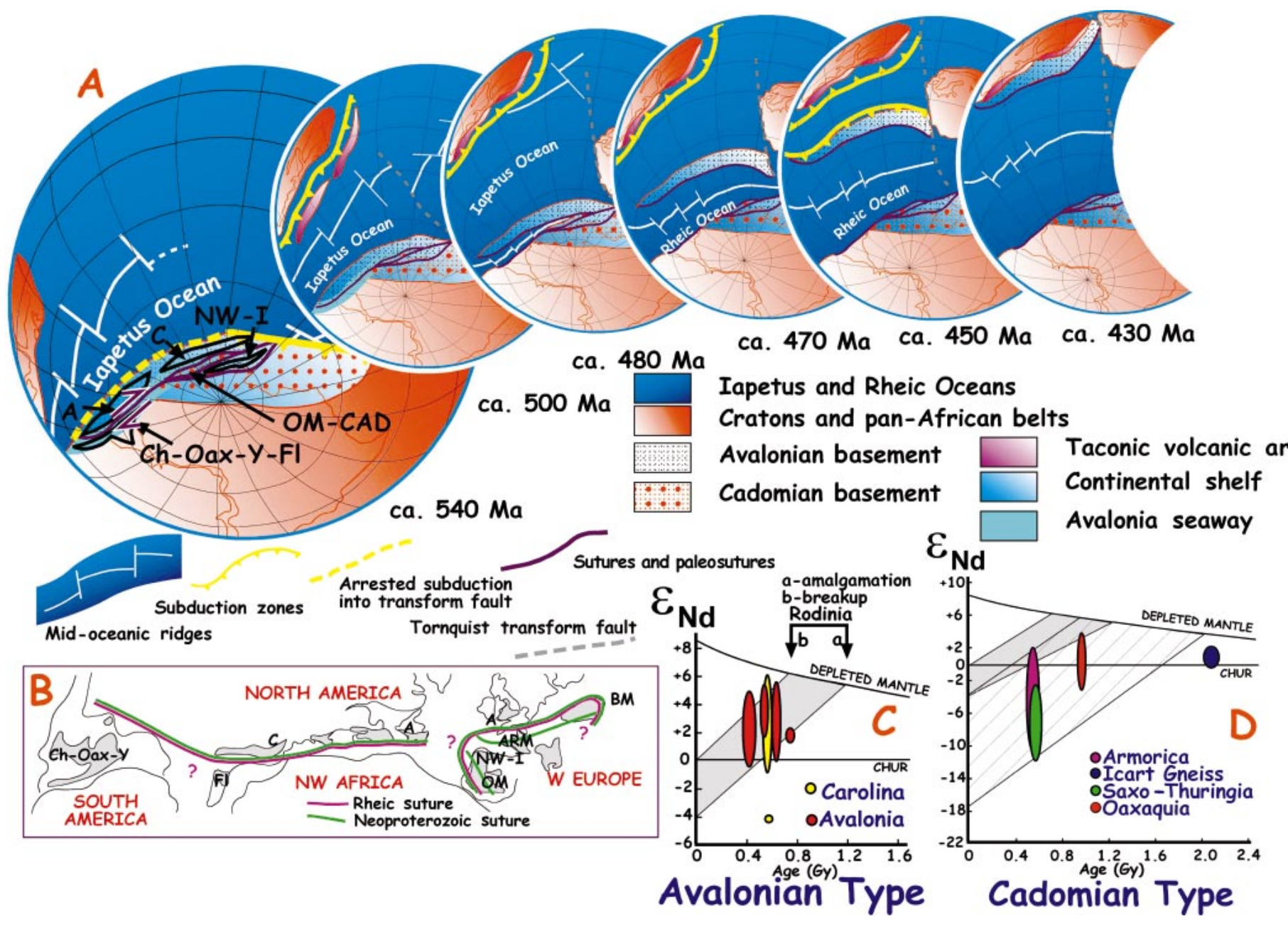

Figure 1. A: Paleozoic reconstructions (modified from Stampfli and Borel, 2002) showing outboard position of Avalonian-type terranes relative to Cadomian-type terranes, their translation along Gondwanan margin in early Paleozoic, their separation from Gondwana with opening of Rheic Ocean, and their accretion to Laurentia with closure of lapetus Ocean. Note that opening of Rheic Ocean coincides with onset of northwesterly directed subduction and subduction of lapetan Ocean ridge along Laurentian margin (see Stampfli and Borel, 2002). B: Early Mesozoic position of peri-Gondwanan terranes mentioned in text (modified from Keppie et al., 2003). Ch-Chortis, Oax-Oaxaquia, Y-Yucatan, FI-Florida, C-Carolina, A-Avalonia, OM-Ossa Morena, CAD-Cadomia, NW-I-northwest Iberia, Arm-Armorica, BMBohemian Massif. C: Sm-Nd isotopic data for Avalonia (A) (from Nance and Murphy, 1996; Murphy et al., 2000) and Carolina (e.g., Samson et al., 1995), which have relatively juvenile signatures. D: Sm-Nd isotopic data for Armorica and Icart Gneiss (Samson et al., 2003) and Saxo-Thuringia (Bohemian Massif, Linnemann et al., 2004), which have more ancient crustal components. Shaded area in C shows field for peri-Rodinian oceanic lithosphere defined by time of amalgamation (a) and breakup (b) of Rodinia, calculated assuming a typical Sm/Nd oceanic crustal ratio of 0.18 . CHUR $=$ chondrite uniform reservoir.

2005). The tectonothermal histories of these peri-Gondwanan terranes show that they continuously faced an open ocean for this time, thereby providing fundamental constraints to paleocontinental reconstructions (e.g., Murphy et al., 2000; Nance et al., 2002; Keppie et al., 2003).

Peri-Gondwanan terranes are characterized by late Neoproterozoic arc-related tectonothermal histories beginning at ca. $760 \mathrm{Ma}$ and peaking at ca. 635-570 Ma with the generation of voluminous arc-related igneous rocks. High-grade metamorphism between ca. 670 and $650 \mathrm{Ma}$ is thought to represent accretion of early Avalonian arcs to the Gondwanan margin (Murphy et al., 2000). Coeval sedimentary successions were deposited in a variety of intra-arc and interarc basins, which were bounded by active faults (e.g., Keppie et al., 2003). Diachronous termination of arc magmatism between ca. 610 and ca. $530 \mathrm{Ma}$ is attributed to the progressive development of a transform system in the latest Neoproterozoic to Early Cambrian (Fig. 1A) resulting from ridgetrench collision, during which some terranes were transferred laterally along the Gondwanan margin (e.g., NW Iberia; Gutierrez-Alonso et al., 2005). This scenario is analogous to the Cenozoic development of the
San Andreas transform fault system of western North America (Murphy et al., 2000; Nance et al., 2002; Keppie et al., 2003).

Despite their broadly similar tectonostratigraphy, peri-Gondwanan terranes (Fig. 1B) can be subdivided into two groups by the contrasting age and composition of their basements: (1) Cadomian-type terranes (northern Armorica, Ossa-Morena, Saxo-Thuringia, Moldanubia), and (2) Avalonian-type terranes (e.g., West Avalonia, East Avalonia, Carolina, Moravia-Silesia, NW Iberia, and possibly Armorica south of the North Armorican shear zone). Only in Armorica is undisputed basement (2.06 Ga Icart Gneiss; Samson and D'Lemos, 1998) exposed in any of the peri-Gondwanan arc terranes. However, the contrasting basement composition of Avalonian-type and Cadomian-type terranes is clear from the very different U-Pb detrital zircon populations in their Neoproterozoic clastic successions and the contrasting Sm-Nd isotopic characteristics of their Neoproterozoic and early Paleozoic crustally derived igneous rocks (Figs. 1C and 1D; e.g., Nance and Murphy, 1996; Samson et al., 2003). The Sm-Nd isotopic composition of Cadomian-type felsic rocks is characterized by predominantly negative 
$\boldsymbol{\varepsilon}_{\mathrm{Nd}}$ values (typically between +1.6 to -9.9 for $t=610 \mathrm{Ma}$ ) and depleted mantle model ages $\left(T_{D M}\right)$ of 1.0 to $2.0 \mathrm{Ga}$ (e.g., Samson and D’Lemos, 1998). In contrast, felsic rocks in Avalonian-type terranes are characterized by $\boldsymbol{\varepsilon}_{\mathrm{Nd}}$ values $(t=610 \mathrm{Ma})$ that range between -1.0 and +5.0 , and $T_{\mathrm{DM}}$ model ages of $0.75-1.1 \mathrm{Ga}$ (e.g., Murphy et al., 2000), and show little overlap with those of Cadomian-type terranes. Available $\mathrm{U}-\mathrm{Pb}$ detrital zircon data for Neoproterozoic clastic successions are similarly distinct. Detrital zircons in Cadomian-type turbidites reveal clusters of ages at $0.60-0.65 \mathrm{Ga}, 2.0-2.2 \mathrm{Ga}, 2.4 \mathrm{Ga}$, and 2.6 Ga (Fernandez-Suarez et al., 2002; Gutierrez-Alonso et al., 2005; Samson et al., 2003), whereas similar-aged clastic successions in Avalonia, NW Iberia, and the Bohemian Massif typically contain populations with ages of $0.6 \mathrm{Ga}, 1.0-1.2 \mathrm{Ga}, 1.5 \mathrm{Ga}, 1.8-2.0 \mathrm{Ga}$, and $2.6 \mathrm{Ga}$ (Keppie et al., 1998; Linnemann et al., 2004).

The combined $\mathrm{Sm}-\mathrm{Nd}$ and $\mathrm{U}-\mathrm{Pb}$ database suggests that the Cadomian arc developed upon 2.0-2.1 Ga crystalline basement (Icart Gneiss), which can be correlated with similar-aged (Icartian) rocks in the West African craton (Samson and D'Lemos, 1998). The range in $\boldsymbol{\varepsilon}_{\mathrm{Nd}}$ values is most simply attributed to the mixing of magmas derived from this Icartian-West African basement with juvenile mantle components of Cadomian (ca. $600 \mathrm{Ma}$ ) age (Nance and Murphy, 1996; Samson and D'Lemos, 1998).

For Avalonian-type terranes, the $0.75-1.1 \mathrm{Ga} T_{\mathrm{DM}}$ model ages suggest derivation of the arc magmas from relatively juvenile (mafic) basement (proto-Avalonia), which was itself extracted from a depleted mantle source during an interval that coincides with the ca. 1.1-0.75 Ga life span of the supercontinent Rodinia. Thus "proto-Avalonia" is inferred to have been formed above one or more subduction zones within the oceanic lithosphere that surrounded Rodinia (Murphy et al., 2000). If so, the basements to the Avalonian-type terranes must have accreted to the northern Gondwanan margin prior to the main 635-570 Ma arc event, at which time the juvenile signature was inherited by arc-related magmas generated by renewed subduction beneath that margin. Evidence of such accretion includes the ca. $650 \mathrm{Ma}$ high-grade metamorphic events recorded in the Avalonian rocks in Britain, southern Newfoundland, Maine, and possibly the Roanoke Rapids terrane in Carolina (e.g., Murphy et al., 2000; Hibbard et al., 2002). Recent studies of terrane accretion in the Canadian Cordillera suggest that such processes can be thick-skinned, and involve up to $100-150 \mathrm{~km}$ of lithosphere, which has isotopic characteristics inherited by younger igneous bodies (e.g., MacKenzie et al., 2005).

The contrasting early histories of the Avalonian- and Cadomiantype terranes imply that a fundamental suture of Neoproterozoic age (ca. $650 \mathrm{Ma}$ ) must have developed along the northern Gondwanan margin between the accreted Avalonian-type and the cratonic Cadomiantype terranes, which is analogous to that between accreted terranes and continental North America in the Cordillera. Additional sutures may have also existed between the various Avalonian-type terranes.

\section{PALEOZOIC HISTORY}

Peri-Gondwanan terranes are characterized by a widespread Cambrian platformal sequence (e.g., Landing, 2005). Faunal and paleomagnetic data indicate a peri-Gondwanan location for the Avalonian-type terranes until the Early Ordovician (e.g., Cocks and Torsvik, 2002), although faunal endemism indicates the temporary presence of a narrow seaway between Avalonia and Gondwana in the Early Cambrian (Landing, 2005).

Recent U-Pb (zircon) and Ar-Ar (muscovite) data from clastic strata in Iberia (Gutierrez-Alonso et al., 2005) suggest that strike-slip displacement of terranes along the Gondwanan margin continued from the late Neoproterozoic into the Cambrian. For example, terranes with Avalonian-type and Cadomian-type basement signatures were juxtaposed prior to the Early Ordovician (ca. $485 \mathrm{Ma}$ ) deposition of the regionally extensive Armorican quartzite (e.g., NW Iberia, SW Iberia; Gutierrez-Alonso et al., 2005), which is thought to reflect the Rheic rift-drift transition. Dextral motion of Avalonian-type terranes relative to the Gondwanan margin is consistent with their outboard position and suggests reactivation of the Neoproterozoic sutures between previously accreted outboard terranes and Gondwana. Such motion might have been accompanied by microplate capture of Avalonia in a manner analogous to the Cenozoic capture of Baja California by the Pacific plate (Keppie et al., 2003), leading to the development of the narrow seaways documented by Landing (2005).

Separation from Gondwana by ca. $485 \mathrm{Ma}$ is supported by the accelerated subsidence recorded in Early Ordovician Avalonian and Gondwanan passive margin sequences in Britain (e.g., Prigmore et al., 1997), and by voluminous bimodal rift-related igneous rocks and thick $(\sim 10 \mathrm{~km})$ passive margin strata in various locations along the Gondwanan margin (e.g., Ossa-Morena zone in Iberia, Sanchez-Garcia et al., 2003; the Acatlan and Oaxacan complexes of Mexico, Keppie et al., 2006). By $460 \mathrm{Ma}$, Avalonia lay at $\sim 40^{\circ} \mathrm{S}$ (Hamilton and Murphy, 2004), about 1700-2000 km south of Laurentia, whereas Gondwana remained at $60^{\circ} \mathrm{S}$ (e.g., Cocks and Torsvik, 2002). This implies a northerly component of drift for Avalonia of $\sim 8 \mathrm{~cm} / \mathrm{yr}$. We view this drift as recording the opening of the Rheic Ocean.

Paleomagnetic studies indicate minimal latitudinal separation between the Carolina terrane and Laurentia by ca. $455 \mathrm{Ma}$, implying that Avalonia was $\sim 2000 \mathrm{~km}$ south of Carolina at this time. However, as Hibbard et al. (2002) pointed out, the current distance between the sampled sites is $\sim 1900 \mathrm{~km}$, so that Carolina and Avalonia could represent the leading and trailing edges, respectively, of the same microplate.

\section{ORIGIN OF THE RHEIC OCEAN}

Avalonia and Carolina were geodynamically linked to the northern Gondwanan margin from ca. $650 \mathrm{Ma}$ to ca. $490 \mathrm{Ma}$, but had drifted $\sim 2000 \mathrm{~km}$ north of this margin by ca. $460 \mathrm{Ma}$. Opening of the Rheic Ocean began with the ca. 500-490 Ma separation of Avalonia and Carolina from Gondwana, while the Cadomian-type terranes remained along the Gondwanan margin (e.g., Cocks and Torsvik, 2002). Hence, the inception of the Rheic Ocean involved the rift and drift of terranes that were outboard of the Neoproterozoic suture zone between the accreted Avalonia-type terranes and cratonic northwestern Gondwana. NW Iberia has Avalonian-type basement yet remained along the Gondwanan margin during initial rifting. We suggest that its Neoproterozoic transfer from a peri-Amazonian realm to a peri-West African realm removed it from its more outboard position (Fig. 1).

The suture zone was reactivated, first in the late Neoproterozoic during oblique subduction associated with the main arc phase, and second during the progressive generation of a transform margin in the Ediacaran-Early Cambrian, at which time, the movement of Avalonia relative to Gondwana may have been accompanied by microplate capture (Keppie et al., 2003). This diachronous generation of a transform margin may have also produced a slab window (Dickinson and Snyder, 1979), resulting in crustal thinning and asthenospheric upwelling that could have caused the voluminous Late Cambrian-Early Ordovician rift-related magmatism and provided the thermally weakened rheology to facilitate the rift-drift transition of Avalonia-Carolina. Such a mechanism would account for the apparent longevity of magmatism after Avalonia-Carolina had separated.

Taken together, the tectonothermal evolution of the Avalonianand Cadomian-type terranes suggests that both the site of initial rifting and the subsequent development of the Rheic Ocean were profoundly influenced by the reactivation of suture zones generated at ca. $650 \mathrm{Ma}$ by the accretion to the Gondwanan margin of the juvenile Avaloniantype basement derived from the peri-Rodinian ocean. If so, the thermal 
structure and style of magmatism and passive margin development during the formation of the Rheic Ocean were profoundly influenced by earlier events.

The actual mechanism of rift-to-drift is uncertain. Several models (e.g., van Staal et al., 1998) imply that the Rheic Ocean initiated as a backarc basin, but evidence for arc-related rocks coeval with rifting along the northern Gondwanan margin is equivocal. Alternatively, since the opening of the Rheic Ocean is coeval with a polarity flip along the northern Iapetus margin and the onset of northwesterly directed subduction and ridge-trench collision (Fig. 1A; e.g., Stampfli and Borel, 2002; van Staal et al., 1998), the portion of the AvalonianCarolinian microplate captured from Gondwana during the Early Cambrian may have been pulled away from Gondwana by slab pull in a manner analogous to the opening of the Neotethys in the Cenozoic (Stampfli and Borel, 2002). This would require the absence of a spreading ridge between Avalonia-Carolina and the Laurentian margin and, given the moderately rapid northerly component of motion of Avalonia between 480 and $460 \mathrm{Ma}$ ( $8 \mathrm{~cm} / \mathrm{yr}$; Hamilton and Murphy, 2004), the presence of a spreading ridge in the Rheic Ocean that was approximately $\mathrm{E}-\mathrm{W}$ in orientation.

\section{ACKNOWLEDGMENTS}

We acknowledge the support of the Natural Sciences and Engineering Council, Canada (Murphy and Dostal), Ministerio de Educacion y Ciencia Research Projects BTE2003-05128 (Gutierrez-Alonso), CGL2004-0463-CO2/BTE (Fernandez-Suarez), and 1FD2003-2324 (Quesada), National Science Foundation grant EAR-0308105 (Nance), and Papiit grant IN103003 (Keppie). We are grateful to Ulf Linnemann, Victor Ramos, Steve Whitmeyer, Nigel Woodcock, and an anonymous reviewer for constructive reviews. This is a contribution to International Geological Correlation Project 497.

\section{REFERENCES CITED}

Cawood, P.A., McCausland, P.J.A., and Dunning, G.R., 2001, Opening Iapetus: Constraints from the Laurentian margin of Newfoundland: Geological Society of America Bulletin, v. 113, p. 443-453.

Cocks, L.R.M., and Torsvik, T.H., 2002, Earth geography from 500 to 400 million years ago: A faunal and palaeomagnetic review: Journal of the Geological Society of London, v. 159, p. 631-644.

Dickinson, W.R., and Snyder, W.S., 1979, Geometry of subducted slabs related to the San Andreas transform: The Journal of Geology, v. 87, p. 609-627.

Fernandez-Suarez, J., Gutierrez-Alonso, G., and Jeffries, T.E., 2002, The importance of along margin terrane transport in northern Gondwana: Insights from detrital zircon parentage in Neoproterozoic rocks from Iberia and Brittany: Earth and Planetary Science Letters, v. 204, p. 75-88.

Gutierrez-Alonso, G., Fernandez-Suarez, J., Collins, A.S., Abad, I., and Nieto, F., 2005, An Amazonian Mesoproterozoic basement in the core of the Ibero-Armorican arc: ${ }^{40} \mathrm{Ar} /{ }^{39} \mathrm{Ar}$ detrital mica ages complement the zircon's tale: Geology, v. 33, p. 637-640.

Hamilton, M.A., and Murphy, J.B., 2004, Tectonic significance of a Llanvirn age for the Dunn Point volcanic rocks, Avalon terrane, Nova Scotia, Canada: Implications for the evolution of the Iapetus and Rheic Oceans: Tectonophysics, v. 379, p. 199-209.

Hatcher, R.D., Jr., 1989, Tectonic syntheses of the U.S. Appalachians, in Hatcher, R.D., et al., eds., The Appalachian-Ouachita orogen in the United States: Boulder, Colorado, Geological Society of America, The Geology of North America, v. F-2, p. 511-535.

Hibbard, J.P., Stoddard, E.F., Secor, D.T., and Dennis, A.J., 2002, The Carolina zone: Overview of Neoproterozoic to early Paleozoic peri-Gondwanan terranes along the eastern flank of the southern Appalachians: EarthScience Reviews, v. 57, p. 299-339.

Keppie, J.D., Davis, D.W., and Krogh, T.E., 1998, U-Pb geochronological constraints on Precambrian stratified units in the Avalon composite terrane of
Nova Scotia, Canada: Tectonic implications: Canadian Journal of Earth Sciences, v. 35, p. 222-236.

Keppie, J.D., Nance, R.D., Murphy, J.B., and Dostal, J., 2003, Tethyan, Mediterranean, and Pacific analogues for the Neoproterozoic-Paleozoic birth and development of peri-Gondwanan terranes and their transfer to Laurentia and Laurussia: Tectonophysics, v. 365, p. 195-219.

Keppie, J.D., Nance, R.D., Fernandez-Suarez, J., Storey, C.D., Jeffries, T.E., and Murphy, J.B., 2006, Detrital zircon data from the eastern Mixteca terrane, southern Mexico: Evidence for an Ordovician-Mississippian continental rise and a Permo-Triassic clastic wedge adjacent to Oaxaquia: International Geology Review, v. 48 (in press).

Landing, E., 2005, Early Paleozoic Avalon-Gondwana unity: An obituaryresponse to "Palaeontological evidence bearing on global OrdovicianSilurian continental reconstructions" by R.A. Fortey and L.R.M. Cocks: Discussion: Earth-Science Reviews, v. 69, p. 169-175.

Linnemann, U., McNaughton, N.J., Romer, R.L., Gehmlich, M., Drost, K., and Tonk, Ch., 2004, West African provenance for Saxo-Thuringia (Bohemian Massif): Did Armorica ever leave pre-Pangean Gondwana? U/PbSHRIMP zircon evidence and the Nd-isotopic record: International Journal of Earth Sciences, v. 93, p. 683-705.

MacKenzie, J.M., Canil, D., Johnston, S.T., English, J., Mihalynuk, M.G., and Grant, B., 2005, First evidence for ultrahigh-pressure garnet peridotite in the North American Cordillera: Geology, v. 33, p. 105-108.

Murphy, J.B., Strachan, R.A., Nance, R.D., Parker, K.D., and Fowler, M.B., 2000, Proto-Avalonia: A 1.2-1.0 Ga tectonothermal event and constraints for the evolution of Rodinia: Geology, v. 28, p. 1071-1074.

Nance, R.D., and Murphy, J.B., 1996, Basement isotopic signatures and Neoproterozoic paleogeography of Avalonian-Cadomian and related terranes in the circum-North Atlantic, in Nance, R.D., and Thompson, M.D., eds., Avalonian and related peri-Gondwanan terranes of the circum-North Atlantic: Geological Society of America Special Paper 304, p. 333-346.

Nance, R.D., Murphy, J.B., and Keppie, J.D., 2002, A Cordilleran model for the evolution of Avalonia: Tectonophysics, v. 352, p. 11-31.

Prigmore, J.K., Butler, A.J., and Woodcock, N.H., 1997, Rifting during separation of Eastern Avalonia from Gondwana: Evidence from subsidence analysis: Geology, v. 25, p. 203-206.

Samson, S.D., and D'Lemos, R.S., 1998, U-Pb geochronology and Sm-Nd isotopic composition of Proterozoic gneisses, Channel Islands, UK: Journal of the Geological Society of London, v. 155, p. 609-618.

Samson, S.D., Hibbard, J.P., and Wortman, G.L., 1995, Nd isotopic evidence for juvenile crust in the Carolina terrane, southern Appalachians: Contributions to Mineralogy and Petrology, v. 121, p. 171-184.

Samson, S.D., D'Lemos, R.S., Blichert-Toft, J., and Vervoort, J., 2003, U-Pb geochronology and Hf-Nd isotope compositions of the oldest Neoproterozoic crust within the Cadomian orogen: New evidence for a unique juvenile terrane: Earth and Planetary Science Letters, v. 208, p. 165-180.

Sanchez-Garcia, T., Bellido, F., and Quesada, C., 2003, Geodynamic setting and geochemical signatures of Cambrian-Ordovician rift-related igneous rocks (Ossa Morena zone, SW Iberia): Tectonophysics, v. 365, p. 233-255.

Stampfli, G.M., and Borel, G.D., 2002, A plate tectonic model for the Paleozoic and Mesozoic constrained by dynamic plate boundaries and restored synthetic oceanic isochrones: Earth and Planetary Science Letters, v. 196, p. $17-33$.

Thomas, W., and Astini, R.A., 1996, The Argentine Precordillera: A traveler from the Ouachita embayment of North America Laurentia: Science, v. 273 , p. $752-757$

van Staal, C.R., Dewey, J.F., Mac Niocaill, C., and McKerrow, W.S., 1998, The Cambrian-Silurian tectonic evolution of the Northern Appalachians and British Caledonides: History of a complex, west and southwest Pacifictype segment of Iapetus, in Blundell, D., and Scott, A.C., eds., Lyell: The past is the key to the present: Geological Society of London Special Publication 143, p. 199-242. 